\title{
The distribution of circulating microRNA and their relation to
}

\section{coronary disease [version 1; peer review: 3 approved]}

\author{
Jane E Freedman1', Bahadir Ercan¹, Kristine M Morin'1, Ching-Ti Liu², \\ Lulufer Tamer ${ }^{3}$, Lokman Ayaz³, Mehmet Kanadasi ${ }^{4}$, Dilek Cicek5, \\ Ali Ihsan Seyhan ${ }^{5}$, Rabia Eker Akilli ${ }^{4}$, Celalettin Camci ${ }^{6}$, Beyhan Cengiz ${ }^{7}$, \\ Serdar Oztuzcu ${ }^{8}$, Kahraman Tanriverdi ${ }^{1}$ \\ ${ }^{1}$ Department of Medicine, University of Massachusetts Medical School, Massachusetts, 01605, USA \\ 2Department of Biostatistics, School of Public Health, Boston University, Boston, 02118, USA \\ ${ }^{3}$ Department of Biochemistry, Mersin University, School of Medicine, Mersin, 33343, Turkey \\ ${ }^{4}$ Department of Cardiology, Cukurova University, School of Medicine, Adana, 01110, Turkey \\ ${ }^{5}$ Department of Cardiology, Mersin University, School of Medicine, Mersin, 33343, Turkey \\ ${ }^{6}$ Department of Oncology, Gaziantep University, School of Medicine, Gazientep, 27310, Turkey \\ ${ }^{7}$ Department of Physiology, Gaziantep University, School of Medicine, Gazientep, 27310, Turkey \\ ${ }^{8}$ Sahinbey Hospital Central Laboratory, Gaziantep University, Gaziantep, 27310, Turkey
}

V1 First published: 19 Nov 2012, 1:50

https://doi.org/10.12688/f1000research.1-50.v1

Latest published: 19 Nov 2012, 1:50

https://doi.org/10.12688/f1000research.1-50.v1

\section{Abstract}

Background: MicroRNAs (miRNAs) are small RNAs that regulate gene expression by suppressing protein translation and may influence RNA expression. MicroRNAs are detected in extracellular locations such as plasma; however, the extent of miRNA expression in plasma its relation to cardiovascular disease is not clear and many clinical studies have utilized array-based platforms with poor reproducibility.

Methods and Results: Initially, to define distribution of miRNA in human blood; whole blood, platelets, mononuclear cells, plasma, and serum from 5 normal individuals were screened for 852 miRNAs using high-throughput micro-fluidic quantitative RT-PCR (qRT-PCR). In total; $609,448,658,147$, and 178 miRNAs were found to be expressed in moderate to high levels in whole blood, platelets, mononuclear cells, plasma, and serum, respectively, with some miRNAs uniquely expressed. To determine the cardiovascular relevance of blood miRNA expression, plasma miRNA ( $n=852$ ) levels were measured in 83 patients presenting for cardiac catheterization. Eight plasma miRNAs were found to have over 2 -fold increased expression in patients with significant coronary disease ( $\geq 70 \%$ stenosis) as compared to those with minimal coronary disease (less than $70 \%$ stenosis) or normal coronary arteries. Expression of miR-494, miR-490-3p, and miR-769-3p were found to have significantly different levels of expression. Using a multivariable regression model including cardiovascular risk factors and medications, hsa-miR-769-3p was found to be significantly correlated with the presence of significant coronary atherosclerosis.

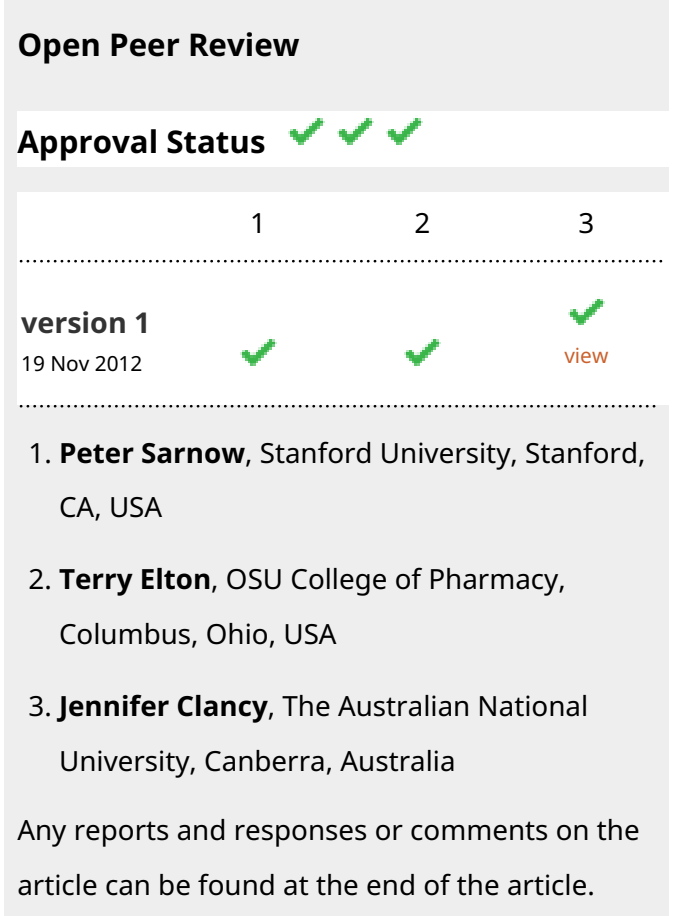


Conclusions: This study utilized a superior high-throughput qRT-PCR based method and found that miRNAs are found to be widely expressed in human blood with differences expressed between cellular and extracellular fractions. Importantly, specific miRNAs from circulating plasma are associated with the presence of significant coronary disease.

\section{Keywords}

Blood, plasma

Corresponding author: Jane E Freedman (jane.freedman@umassmed.edu)

Competing interests: No competing interests were disclosed.

Grant information: This work was partially supported by HL087201 (Jane E. Freedman). The funders had no role in study design, data collection and analysis, decision to publish, or preparation of the manuscript.

Copyright: @ 2012 Freedman JE et al. This is an open access article distributed under the terms of the Creative Commons Attribution License, which permits unrestricted use, distribution, and reproduction in any medium, provided the original work is properly cited. Data associated with the article are available under the terms of the Creative Commons Zero "No rights reserved" data waiver (CC0 1.0 Public domain dedication).

How to cite this article: Freedman JE, Ercan B, Morin KM et al. The distribution of circulating microRNA and their relation to coronary disease [version 1; peer review: 3 approved] F1000Research 2012, 1:50 https://doi.org/10.12688/f1000research.1-50.v1

First published: 19 Nov 2012, 1:50 https://doi.org/10.12688/f1000research.1-50.v1 


\section{Introduction}

MicroRNAs (miRNAs) are 20-26-nt single stranded RNAs that participate in the regulation of various biological functions in numerouseukaryotic lineages, including plants, insects, vertebrate, and mammals ${ }^{1-3}$. More than 850 human miRNAs have been cloned and bioinformatic predictions indicate that mammalian miRNAs can regulate approximately $30 \%$ of all protein-coding genes ${ }^{4-6}$. The expression of many miRNAs is specific to a tissue or developmental stage, and the miRNA expression pattern is altered during the development of several diseases ${ }^{7,8}$.

Studies measuring small numbers of miRNAs have shown their presence in circulating blood; specifically in platelets ${ }^{9}$, plasma $^{10}$, and mononuclear cells ${ }^{11}$. In studies examining specific miRNAs ${ }^{12,13}$, differential expression was noted both in hematopoietic cell lines ${ }^{13}$ and between human and mouse cells ${ }^{12}$. Interestingly, miRNAs have been detected in cell-free human plasma preparations ${ }^{14}$. They have been found to be stable and protected from endogenous RNase activity ${ }^{14}$. In addition, levels of a specific miRNA ( $\left.m i R-141\right)$ can distinguish patients with prostate cancer from healthy controls ${ }^{14}$.

Basic studies have shown that miRNAs regulate cardiac differentiation, angiogenesis, and myocyte growth ${ }^{15,16}$. Small clinical studies have also shown that levels of specific miRNA have been correlated with myocardial infarction in cardiac tissue from humans ${ }^{17}$ and animal models $^{18,19}$. A recent study examined one miRNA ( $\left.m i R-1\right)$ from plasma and related it to acute myocardial infarction ${ }^{10}$. In stable and unstable coronary artery disease patients, 157 miRNAs were measured from peripheral blood mononuclear cells and differential expression was found ${ }^{11}$.

As shown by these studies, there are some publications about circulating miRNAs in cardiovascular disease ${ }^{9,20}$. In addition, the existing studies are restricted by incomplete evaluation of currently known miRNAs. Available arrays are constrained by incomplete miRNA coverage, issues in discriminating between closely related miRNAs, as well as ongoing discovery of new miRNAs (and the inherent lack of flexibility of the array platform). In addition, miRNA arrays have poor reproducibility when across clinical populations or in larger samples sizes ${ }^{21}$. We have developed a combined method of miScript miRNA assays (Qiagen, Germantown, MD) and Dynamic Arrays (Fluidigm, South San Francisco, CA) that employs quantitative RTPCR (qRT-PCR) using a high-throughput process that allows us to analyze more samples vs. more miRNAs in a very short time ${ }^{22}$. Lastly, unlike hybridization-based microarray profiling techniques, qRT-PCR is considered the gold standard for RNA expression and does not require further confirmation analysis. Using this platform, a complete analysis of circulating whole blood, cellular, and cell-free miRNA was performed. The relevance of these findings to coronary disease was determined by measuring plasma miRNA expression in patients presenting for coronary angiography. The findings suggest that the distinct patterns of miRNA expression in components of whole blood may reflect specific patterns of disease.

\section{Results}

miRNA profile in human plasma, serum, platelets, mononuclear cells and whole blood

There is minimal information defining miRNA expression in human blood and a complete screen of all known miRNAs has never been reported due to the limitations of current arrays and the cost of extensive qRT-PCR screening. Using blood samples from normal subjects and high-throughput qRT-PCR, the miRNA expression profile was determined for whole blood, isolated platelets, mononuclear cells, plasma and serum from five healthy subjects. Of the 852 miRNAs measured (Supplemental Table 1), the distribution of circulating miRNA that were most abundantly expressed in plasma and many of the blood derived sources is shown in Table 1. Gene expression is listed as cycle threshold value $(\mathrm{Ct})$ consistent with RTPCR-based data. Because the Ct values are listed, higher gene expression is reflected by a lower number. A complete list of miRNA expression for all sources is shown in Supplemental Table 2 (mean $\mathrm{Ct}$ value) and Supplemental Table 3 (mean delta Ct, accounting for housekeeping gene hsa-RNU1A-1). Unlike mRNA expression, it is currently unclear if miRNA data is more reliable when normalized with a housekeeping gene. This is especially germane for the cell-free plasma samples where a fixed volume was used and gene expression does not need to be normalized for cell count.

miRNA results and demographic data

1 Data File

http://dx.doi.org/10.6084/m9.figshare.97385

\section{List of all miRNA assays}

1 Data File

http://dx.doi.org/10.6084/m9.figshare.97386

Unique distribution of miRNAs expressed in plasma, peripheral blood mononuclear cells (PBMCs), platelets, whole blood and serum. Average $\mathrm{Ct}$ values shown

1 Data File

http://dx.doi.org/10.6084/m9.figshare.97387

Unique distribution of miRNAs expressed in plasma, peripheral blood mononuclear cells (PBMCs), platelets, whole blood and serum. Average delta $\mathrm{Ct}$ values shown, housekeeping gene HsRNU1A-1 used to calculate delta $\mathrm{Ct}$

1 Data File

http://dx.doi.org/10.6084/m9.figshare.97388

Expression of plasma miRNAs in patients with $\geq 70 \%$ CAD, patients with $\leq 70 \%$ CAD, and normal arteries. Data are expressed as mean delta $\mathrm{Cts}$ and standard deviation

1 Data File

http://dx.doi.org/10.6084/m9.figshare.97389

One-hundred and ninety four miRNAs were not expressed in any of the blood-based samples. Peripheral blood mononuclear cells (PBMCs) contained the highest number of miRNAs (658) followed by whole blood (609), platelets (448), serum (178) and plasma (147). As the abbreviated list shown in Table 1 demonstrates, while there 
Table 1. Expression of miRNAs from whole blood, isolated platelets, mononuclear cells, plasma, and serum from healthy subjects (mean $\mathrm{Ct}$ values has shown; higher value indicates lower expression).

\begin{tabular}{|c|c|c|c|c|c|}
\hline miRNA Name & Plasma & PBMCs & Platelets & $\begin{array}{l}\text { Whole } \\
\text { blood }\end{array}$ & Serum \\
\hline hsa-miR-1234 & 14.68 & 14.13 & 13.34 & 15.08 & 13.22 \\
\hline hsa-miR-641 & 15.20 & 14.66 & 14.43 & 15.08 & 15.50 \\
\hline hsa-miR-124a & 15.63 & 17.54 & 17.25 & 18.59 & 18.25 \\
\hline hsa-miR-933 & 15.64 & 12.37 & 13.99 & 12.30 & 14.66 \\
\hline hsa-miR-7-2* & 15.87 & 16.30 & 17.58 & 16.42 & 18.38 \\
\hline hsa-miR-323-3p & 16.53 & 15.06 & 15.26 & 15.08 & 15.51 \\
\hline hsa-miR-631 & 17.34 & 15.96 & 16.43 & 16.43 & 17.01 \\
\hline hsa-miR-566 & 17.81 & 15.56 & 19.99 & 15.47 & 17.36 \\
\hline hsa-miR-1185 & 17.97 & $\mathrm{~N} / \mathrm{A}$ & $\mathrm{N} / \mathrm{A}$ & N/A & $\mathrm{N} / \mathrm{A}$ \\
\hline hsa-miR-766 & 17.98 & 13.70 & 15.76 & 13.94 & 16.55 \\
\hline hsa-miR-625* & 18.03 & 20.71 & 19.75 & 20.90 & 18.80 \\
\hline hsa-miR-1228 & 18.06 & 14.63 & 17.15 & 16.36 & 18.07 \\
\hline hsa-miR-628 & 18.17 & 18.10 & 17.29 & 18.13 & 17.71 \\
\hline hsa-miR-601 & 18.38 & 15.22 & 17.46 & 15.73 & 18.85 \\
\hline hsa-miR-1281 & 18.78 & 16.72 & 16.65 & 16.75 & 17.14 \\
\hline hsa-miR-636 & 18.94 & 15.46 & 17.50 & 15.47 & 18.54 \\
\hline hsa-miR-657 & 19.04 & 19.11 & 17.50 & 19.39 & 18.50 \\
\hline hsa-miR-33b* & 19.48 & 18.82 & 21.05 & 18.80 & 20.59 \\
\hline hsa-miR-553 & 19.51 & $\mathrm{~N} / \mathrm{A}$ & $\mathrm{N} / \mathrm{A}$ & N/A & $\mathrm{N} / \mathrm{A}$ \\
\hline hsa-miR-148a* & 19.76 & 17.90 & 20.00 & 18.05 & 20.47 \\
\hline hsa-miR-637 & 20.09 & 17.88 & 18.08 & 18.25 & 19.65 \\
\hline hsa-miR-375 & 20.24 & 18.52 & 18.99 & 17.80 & 19.35 \\
\hline hsa-miR-129-3p & 20.24 & 20.78 & 20.18 & 20.44 & 20.57 \\
\hline hsa-miR-99b & 20.31 & 17.33 & 19.18 & 18.73 & 19.49 \\
\hline hsa-miR-380-5p & 20.33 & 15.62 & 17.80 & 16.05 & 18.00 \\
\hline hsa-miR-508-5p & 20.36 & 23.27 & $\mathrm{~N} / \mathrm{A}$ & 24.04 & $\mathrm{~N} / \mathrm{A}$ \\
\hline hsa-miR-1178 & 20.36 & 21.76 & 20.42 & 23.43 & 20.10 \\
\hline hsa-miR-92a & 20.54 & 12.14 & 12.23 & 8.94 & 20.42 \\
\hline hsa-miR-888 & 20.55 & 20.25 & 18.76 & 20.30 & 18.72 \\
\hline hsa-miR-525* & 20.59 & 24.62 & $N / A$ & $\mathrm{~N} / \mathrm{A}$ & $\mathrm{N} / \mathrm{A}$ \\
\hline hsa-miR-875-3p & 20.63 & 18.91 & 20.36 & 18.98 & 20.64 \\
\hline hsa-miR-876-5p & 20.64 & 20.37 & 22.90 & 21.25 & 20.37 \\
\hline hsa-miR-630 & 20.74 & 18.22 & 18.06 & 18.55 & 21.05 \\
\hline hsa-miR-519e & 20.79 & 24.38 & $\mathrm{~N} / \mathrm{A}$ & 24.63 & $N / A$ \\
\hline hsa-miR-632 & 20.84 & 16.96 & 19.90 & 17.08 & 20.58 \\
\hline hsa-miR-1301 & 20.86 & 19.18 & 19.74 & 19.85 & 20.22 \\
\hline hsa-miR-654 & 20.87 & 16.66 & 19.45 & 16.88 & 19.89 \\
\hline $\begin{array}{l}\text { hsa-miR-548a- } \\
5 p\end{array}$ & 20.90 & $\mathrm{~N} / \mathrm{A}$ & $N / A$ & N/A & $\mathrm{N} / \mathrm{A}$ \\
\hline hsa-miR-877* & 21.16 & 19.21 & 21.59 & 19.60 & 21.38 \\
\hline GAPDH & 21.17 & 14.52 & 17.52 & 15.06 & 22.86 \\
\hline
\end{tabular}

is consistency between the groups, some miRNAs are more highly expressed in select sources. Sixty miRNAs were expressed in all five components. As the precise source of miRNA in plasma is not yet known, there was particular interest in comparing the expression between plasma and cellular miRNA patterns. Based on the significant overlap between the groups, it is difficult to determine the source for many of the specific plasma-derived miRNAs. It is not clear from the current data which miRNAs have a non-blood-based cellular source. Interestingly, miR-1185 and miR-548a-5p were much more abundantly expressed in plasma as compared to PBMCs or platelets, or only expressed in plasma. Although an interesting observation, the source of these two miRNAs cannot be determined from this data. In addition, some genes were expressed in platelets or PBMCs and not whole blood. This is likely due to the greater dilution used with PAXgene tubes and the loss of measurable expression of less abundant miRNAs.

\section{Plasma miRNA expression in patients with and without significant coronary disease}

The initial hypothesis of this study was that patients with significant coronary disease would have altered expression of plasma miRNA. Patients were divided into two groups (Table 2 ); 1 ) $\geq 70 \%$ coronary stenosis of any coronary artery or 2 ) $<70$ coronary stenosis. There were notable differences in expression of some of the miRNAs between these two groups (Table 3). By direct comparison, several plasma miRNAs were found to have over 2-fold increased expression in patients with significant coronary disease $(\geq 70 \%)$ as compared to those with minimal coronary disease or normal coronary arteries (Figure 1). Initial statistical analysis demonstrated that antihypertensive therapy, smoking, and lipid lowering therapy have a positive association with coronary artery status (Table 2 ). Increased expression of miR-494, miR-769-3p and miR-490-3p was associated with $\geq 70 \%$ coronary stenosis. Next, the six variables were fit into a logistic regression analysis. As seen in Table 4, anti-hypertensive therapy, smoking and miR-769-3p were significantly associated with the coronary status.

Table 2. Characteristics of catheterization sample participants. Continuous measures, mean \pm S.D., or number and percent with stated characteristic.

\begin{tabular}{|c|c|c|c|c|}
\hline & \multicolumn{2}{|c|}{$\begin{array}{c}\text { Non CAD } \\
\text { group (<70 CAD) n } 49\end{array}$} & \multicolumn{2}{|c|}{$\begin{array}{c}\text { CAD } \\
\text { group }(\geq 70 \text { CAD) n } 34\end{array}$} \\
\hline & Mean & SD & Mean & SD \\
\hline Age & 56.2 & 11.3 & 61.3 & 10.6 \\
\hline Male & 28.0 & & 27.0 & \\
\hline Female & 22.0 & & 7.0 & \\
\hline Hypertension & 21 & & 27 & \\
\hline Smoking & 8 & & 19 & \\
\hline Lipid treatment & 6 & & 16 & \\
\hline Diabetes & 10 & & 7 & \\
\hline Family history & 14 & & 11 & \\
\hline $\begin{array}{l}\text { Antihypertensive } \\
\text { therapy }\end{array}$ & 13 & & 28 & \\
\hline $\begin{array}{l}\text { Hormone } \\
\text { replacement } \\
\text { therapy }\end{array}$ & 13 & & 10 & \\
\hline Glucose & 129.3 & 71.3 & 135.1 & 76.2 \\
\hline Total cholesterol & 169.9 & 36.6 & 168.4 & 40.5 \\
\hline $\mathrm{HDL}$ & 39.5 & 8.8 & 36.5 & 12.5 \\
\hline LDL & 99.2 & 29.5 & 94.4 & 34.0 \\
\hline Triglyceride & 171.6 & 108.2 & 182.6 & 100.4 \\
\hline
\end{tabular}




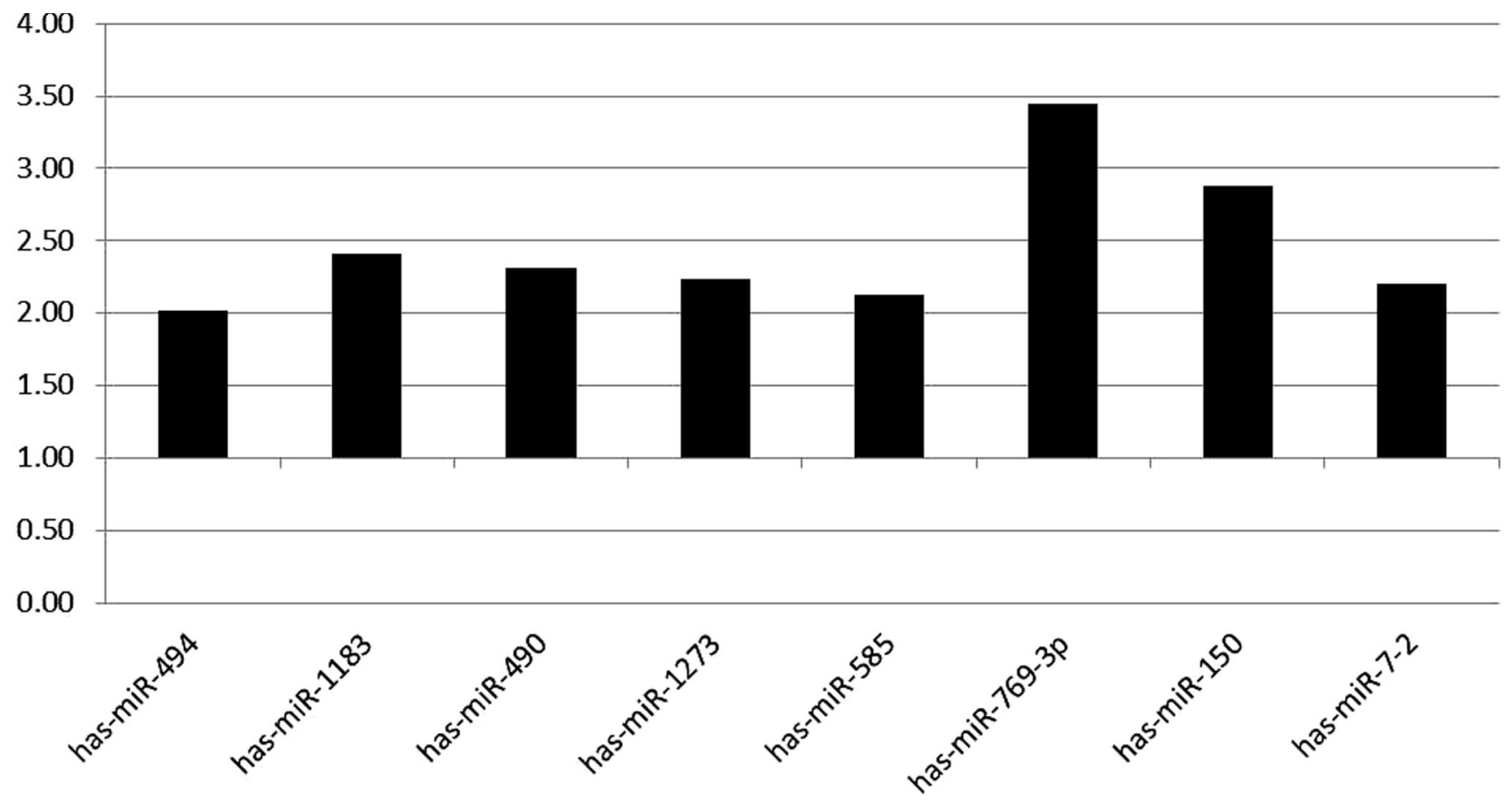

Figure 1. Fold change in plasma miRNA expression between in two groups. miRNAs shown had expression increased $>2$-fold between the groups; 1 ) $\geq 70 \%$ coronary stenosis of any coronary artery or 2$)<70$ coronary stenosis.

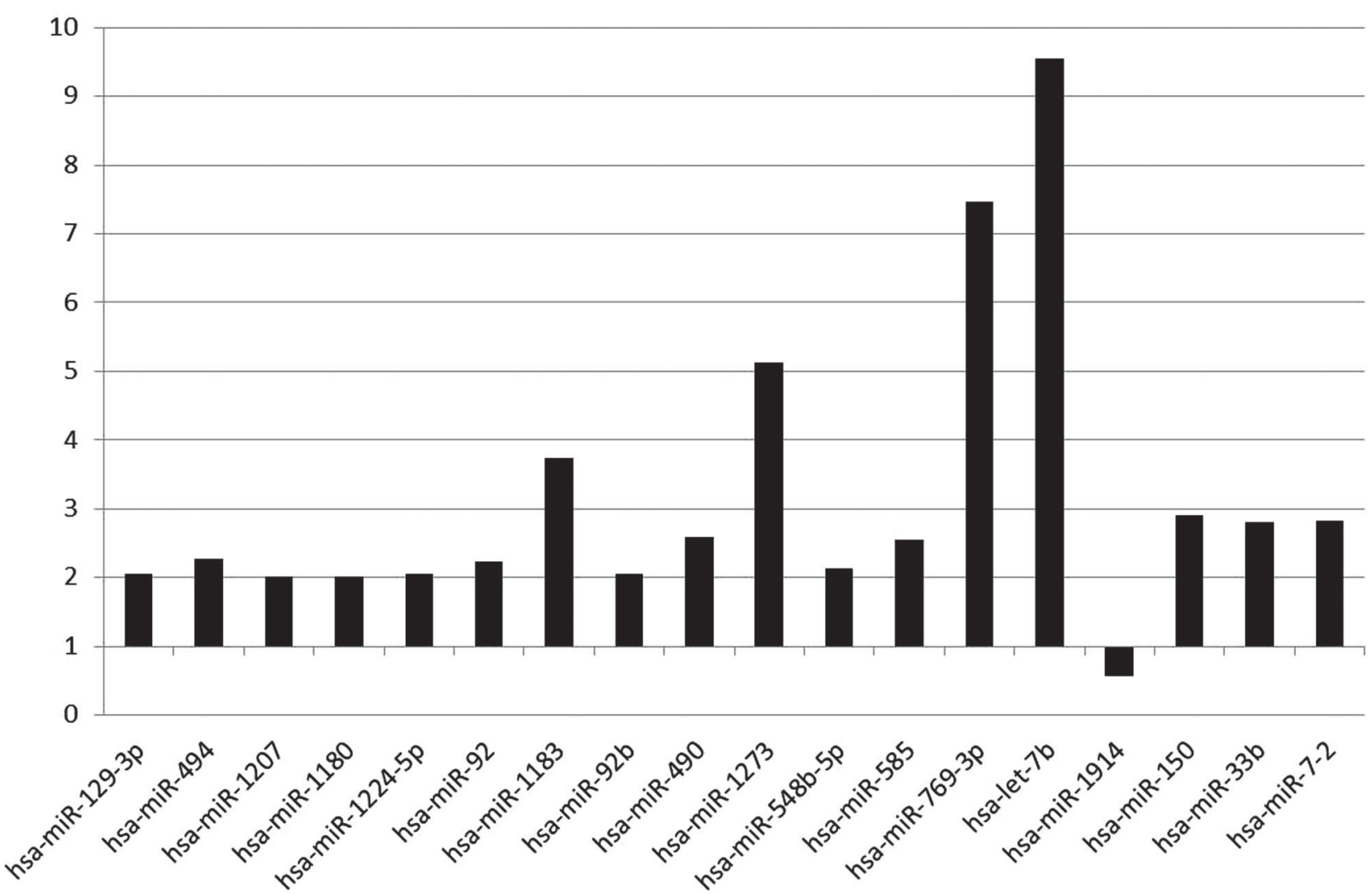

Figure 2. Fold change in plasma miRNA expression between three groups. miRNAs shown had expression increased $>2$-fold or decreased $<0.5$-fold for the groups; 1) patients with CAD; at least one of the coronary arteries have $\geq 70 \%$ occlusion; 2) patients with atherosclerosis but not clinically significant CAD; coronary occlusion $1 \%-<70 \%$; and 3) coronary atherosclerosis-free, patients with no angiographically documented coronary artery stenosis. 
Table 3. Expression of plasma miRNAs in patients with $\geq \mathbf{7 0} \%$ CAD as compared to patients with $<70 \%$ CAD or normal arteries. Data is expressed as the mean delta Ct (Normalized to the RNU1A) and standard deviation. A lower number indicates increased miRNA expression. Bold valuesones are associated with CAD. More explanation in Table 5.

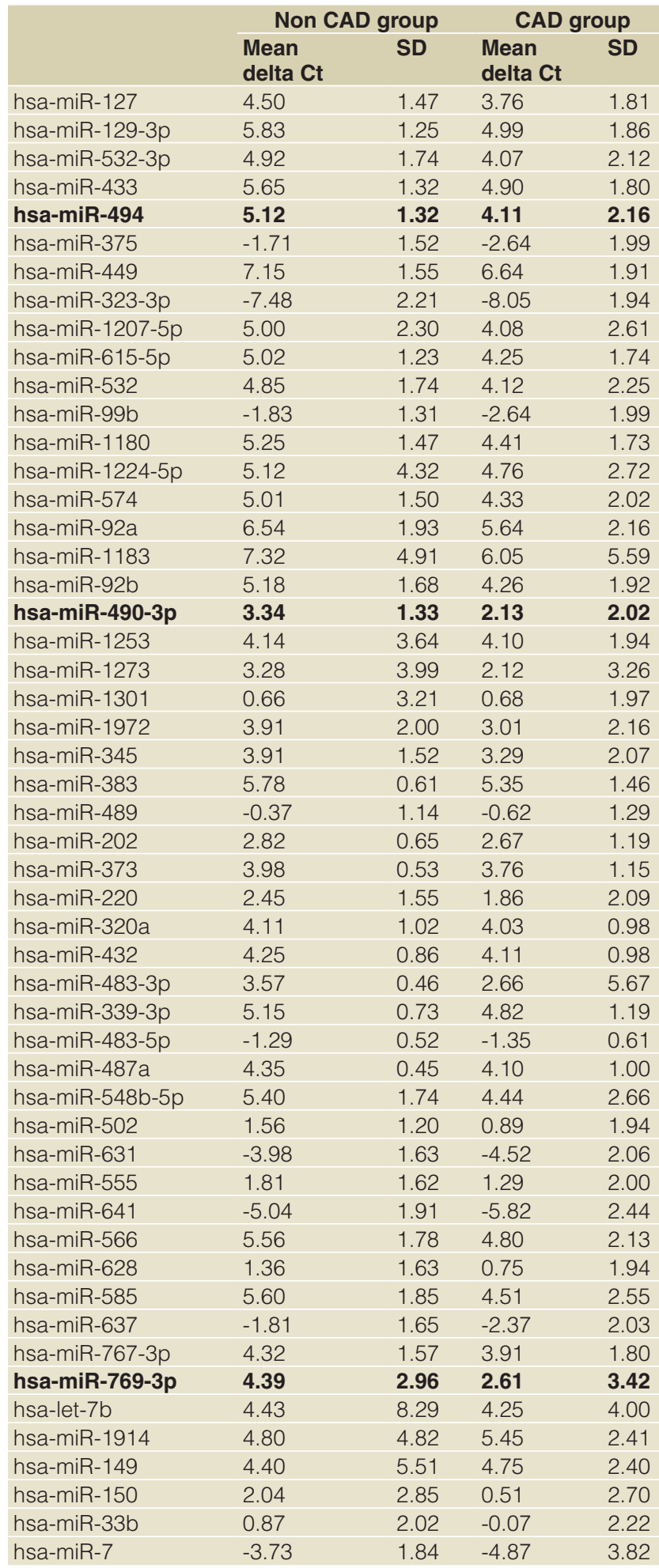

Table 4. Logistic regression analysis using demographic characteristics and significantly differentially expressed miRNAs.

\begin{tabular}{|c|c|c|c|c|}
\hline & Estimate & $\begin{array}{l}\text { Std. } \\
\text { Error }\end{array}$ & $z$ value & $\operatorname{Pr}(>|z|)$ \\
\hline (Intercept) & -1.63 & 1.12 & -1.44 & 0.14 \\
\hline $\begin{array}{l}\text { Antihypertensive } \\
\text { therapy }\end{array}$ & 2.86 & 0.77 & 3.70 & $0.000213^{* * *}$ \\
\hline Smoking & 2.44 & 0.77 & 3.16 & 0.001568 ** \\
\hline $\begin{array}{l}\text { Lipid lowering } \\
\text { therapy }\end{array}$ & 0.74 & 0.73 & 1.01 & 0.30 \\
\hline hsa-miR-494 & 0.05 & 0.27 & 0.20 & 0.83 \\
\hline hsa-miR-490-3p & -0.30 & 0.31 & -0.96 & 0.33 \\
\hline hsa-miR-769-3p & -0.23 & 0.11 & -1.98 & 0.047044 * \\
\hline
\end{tabular}

\section{Plasma miRNA expression: significant coronary} disease vs. disease-free

We initially determined whether presence of significant coronary disease, as defined by $\geq 70 \%$ stenosis is associated with specific miRNA expression. A secondary question is whether presence/ absence of coronary disease is associated with miRNA expression. To study this, patients were placed into one of three groups; 1) patients with $\mathrm{CAD}$; at least one of the coronary arteries have $\geq 70 \%$ occlusion; 2 ) patients with minimal CAD; coronary occlusion 1\%-<70\%; and 3) coronary atherosclerosis-free, patients with no angiographically documented coronary artery stenosis. Because the numbers are small, a simple (non-statistical) comparison was made to determine trends. As seen in Figure 2 and Supplemental table 4, 18 miRNAs had a varied expression pattern between group 1 and group 3. Seventeen miRNAs were upregulated at least 2-fold with only miR-1914 downregulated 0.5-fold. Interestingly, most miRNAs demonstrated a dose response with the greatest expression in patients with the most coronary disease and the least expression in disease-free patients (Supplemental table 4).

\section{miRNA target predictions}

Currently, the capacity to measure miRNAs far outpaces our ability to understand their function in a given tissue. However, to better understand the potential significance of our findings, we conducted analyses that predict targets of the miRNAs that were up- or downregulated in coronary disease using two methods; current publications (www.ncbi.nlm.nih.gov/pubmed/) and TARGETSCAN 5.1 (www.targetscan.org). Using these methods, results for miRNA targets varied between 3 to 369 targets per miRNA when identified. With the TARGETSCAN search, target genes for individual miRNAs were identified using the context score for specific sites within genes. The context score is the sum of site-type contribution, 3' pairing contribution, local AU contribution, and position contribution. The lower the context score indicates the most highly predicted targets for each miRNA. By TARGETSCAN search, miRNAs miR-1914 and miR-7-2, had no target gene identified.

Detailed predictions for the miRNAs found to be significant in CAD are shown in Table 5. In broad terms, some miRNAs appear 
to target transcription factors, growth factors, cytokine regulation, transmembrane proteins, signal transduction pathways, and epigenetic pathways such as histone acetylases. Prediction results for specific miRNAs in TARGETSCAN include the following: miR129-3p and miR-494 target HMGCS1; miR-150 targets MMP14; miR-150, and 92b target MMP16. Additionally, miR-1207 appears to target energy metabolism (most likely involving glucose metabolism).

We also analyzed the miRNAs that were unique to plasma, miR1185-1 and miR-548a-5p-1. While many potential targets were identified, these miRNAs were predicted to target genes involved in controlling transcription factors, as well as several growth and cell cycle components.

\section{Discussion}

MicroRNAs (miRNAs) are short regulatory RNAs that participate in the control of approximately $30 \%$ of all protein-coding genes $^{4-6}$. The expression of many miRNAs is usually specific to a tissue or developmental stage, and the miRNA expression pattern is altered during the progression of several diseases ${ }^{7,8}$. Most miRNAs are transcribed by RNA polymerase II from individual miRNA genes, from introns of protein coding genes, or from polycistronic transcripts that often encode multiple related miRNAs ${ }^{4,23}$. Although

Table 5. MiRNA predictions for target genes associated with significant coronary disease using TARGETSCAN. Individual miRNAs target genes identified as significantly different between patients with and without significant coronary disease were selecting using the context score, a sum of; site-type contribution, 3' pairing contribution, local AU contribution, and position contribution. The lowest scores show highest predictions.

\begin{tabular}{|c|c|c|}
\hline Target gene & Gene name/miRNA name & Total context score \\
\hline \multicolumn{3}{|c|}{ hsa-miR-494* } \\
\hline SOCS6 & Suppressor of cytokine signaling 6 & -1.06 \\
\hline HMGCS1 & 3-hydroxy-3-methylglutaryl-Coenzyme A synthase 1 (soluble) & -0.88 \\
\hline COL6A6 & Collagen type VI alpha 6 & -0.64 \\
\hline BCAP29 & B-cell receptor-associated protein 29 & -0.53 \\
\hline SCARB2 & Scavenger receptor class B, member 2 & -0.52 \\
\hline IGF1R & Insulin-like growth factor 1 receptor & -0.31 \\
\hline F11R & F11 receptor & -0.41 \\
\hline \multicolumn{3}{|c|}{ hsa-miR-490-3p* } \\
\hline LEP & Leptin & -0.32 \\
\hline IL1RAP & Interleukin 1 receptor accessory protein & -0.31 \\
\hline CD63 & CD63 molecule & -0.29 \\
\hline TGFBR1 & Transforming growth factor, beta receptor I (activin A receptor type II-like kinase, 53kDa) & -0.21 \\
\hline ADIPOR2 & Adiponectin receptor 2 & -0.2 \\
\hline MEF2D & Myocyte enhancer factor 2D & 0 \\
\hline \multicolumn{3}{|c|}{ hsa-miR-769-3p* } \\
\hline FAM130A1 & Family with sequence similarity 130, member $\mathrm{A} 1$ & -0.4 \\
\hline SHPK & Sedoheptulokinase & -0.39 \\
\hline KCNA5 & Potassium voltage-gated channel, shaker-related subfamily, member 5 & -0.35 \\
\hline MARCKS & Myristoylated alanine-rich protein kinase $\mathrm{C}$ substrate & -0.25 \\
\hline PBRM1 & Polybromo 1 & -0.24 \\
\hline ISOC2 & Isochorismatase domain containing 2 & -0.23 \\
\hline MYCL1 & V-myc myelocytomatosis viral oncogene homolog 1 , lung carcinoma derived (avian) & -0.23 \\
\hline KPNA6 & Karyopherin alpha 6 (importin alpha 7) & -0.2 \\
\hline KDSR & 3-ketodihydrosphingosine reductase & -0.17 \\
\hline COLEC12 & Collectin sub-family member 12 & -0.15 \\
\hline TSPAN1 & Tetraspanin 1 & -0.15 \\
\hline PIM2 & Pim-2 oncogene & -0.11 \\
\hline KIAA1128 & Family with sequence similarity 190, member B (FAM190B) & -0.07 \\
\hline
\end{tabular}


miRNAs can guide mRNA cleavage, the basic function of miRNA is to mediate inhibition of protein translation ${ }^{1,7,24-27}$ through miRNA-induced silencing complexes (miRISCs). The guiding strand of miRNA in a miRISC interacts with a complementary sequence in the 3'-untranslated region (3'-UTR) of its target mRNA by partial sequence complementarities, resulting in translational inhibition ${ }^{1,7}$.

In this study, the distribution of miRNA expression in whole blood, platelets, PBMCs plasma and serum showed significant overlap. Of particular interest are the nucleus-lacking platelet and the cell-free plasma expression levels. A primary question is why platelets would have miRNA? Platelets are produced in the bone marrow from megakaryocytes as cytoplasmic fragments without genomic DNA ${ }^{28}$. Platelets, however, retain a small amount of megakaryocyte-derived messenger RNAs (mRNAs) that have recently been suggested to be of physiological significance. Platelets can respond to physiological stimuli at the levels of protein translation and mRNA splicing ${ }^{29,30}$. There are few published studies describing platelet miRNAs ${ }^{13}$. In this study, cells of hematopoietic lineage were described to have a limited number of miRNAs (this study only tested for 19 miRNAs) and functionality was not shown. Interestingly, our data demonstrate that platelets express nearly the same number of miRNAs as PBMCs. The number of miRNAs in PBMCs is slightly less than in whole blood with the reason likely being dilution of low abundant PBMC miRNAs in whole blood.

In limited numbers, miRNAs have been detected in cell-free human plasma preparations ${ }^{14}$. They have been found to be stable and protected from endogenous RNase activity ${ }^{14}$. In addition, levels of a specific miRNA ( $m i R-141)$ can distinguish patients with prostate cancer from healthy controls. In our analysis, we found moderate to high levels of expression of miRNAs in plasma in both normal subjects and patients with coronary disease, albeit in lower numbers as compared to platelets and PBMCs. What these data do not provide is the specific source of circulating miRNAs. This is a fundamental and fascinating question. They are believed to arise from three potential mechanisms: apoptosis, cellular activation with release of protrusions, and microsome/microvesicle formation. For example, Mitchell et al. found miR-141 differentially expressed in plasma in microsomes of prostate cancer patients ${ }^{14}$. It is possible that the miRNAs detected by our measurements in plasma or blood could be derived from endothelial cells or the atherosclerotic plaque itself. Further fundamental experiments are needed to answer this question. Recently, it has been shown that HDL particles deliver miR$\mathrm{NAs}^{31}$. Additionally, Wang et al. reported that plasma and whole blood miR-133 and miR-328 levels are increased in AMI patients ${ }^{32}$.

By the current data, we cannot assign precise punitive targets; however, specific bioinformatics approaches have been developed to predict miRNAs present in the genome of different organisms. These techniques are based on the observation that transcripts are usually highly conserved between related species and produced from precursor transcripts of similar size and structure. Using these bioinformatics approaches and the limited information available in the literature, we assembled potential target genes for the miRNAs expressed in significantly different amounts between patients with and without $\geq 70 \%$ coronary disease (Table 5 ). The list included a diverse range of functional and structural genes. This includes leukocyte and platelet recruitment to the atherosclerotic tissues, matrix reorganization, foam cell formation, growth/proliferation, and angiogenesis. However, these predictions do not provide definitive targets and additional basic studies are needed to provide clearer mechanistic information.

Also unique to our study is the specific method of measurement we used, which allowed for flexibility in adding newly discovered miRNAs, the use of small volumes, and high-throughput methods for qRT-PCR. Currently, there are several miRNA microarray products available that measure fewer miRNAs and some consist of older versions of the Sanger miRBase Sequence Database. Using the universal cDNA reaction feature of miScript provided the ability to profile all miRNAs with one cDNA reaction. Unlike the hybridization-based microarray profiling techniques, by coupling the miScript and Biomark Systems, confirmation analysis was not required for individual miRNAs. However, there are important limitations of our study. Despite the expansive miRNA survey for blood components, we cannot define the specific source for the plasma miRNA nor its eventual destination. Our study of coronary patients was limited by only being able to evaluate plasma miRNA, as other blood components were not available to us. In addition, while the miRNA data provided from these patients are unique, the numbers are still small making further analysis based on any subgroup statistically unfeasible.

In summary, miRNAs are small RNAs that play an important role in the negative regulation of gene expression by suppressing protein translation and have been detected in cell-free plasma and have been related to select diseases. By examining all measurable miRNAs, we defined the relative expression in blood components and find significant expression in platelets, PBMCs, whole blood, plasma and serum. By comparing plasma miRNA expression in patients with coronary disease, we begin to define specific miRNAs that are altered and provide potential targets that influence atherosclerosis.

\section{Materials and methods}

\section{Sample procurement}

This study was approved by Mersin University Ethical Committee $(06 / 05 / 2009$, \#6/144) and written consent was obtained from the subjects to test the hypothesis of whether coronary occlusion of $\geq 70 \%$ is associated with increased plasma miRNA expression levels. Upon enrollment, a study coordinator identified the presence of the following risk factors: (1) age, (2) male sex, (3) clinical history of diabetes, (4) clinical history of hypertension, (5) cigarette smoking, (6) clinical history of hypercholesterolemias, and (7) family history of coronary disease. Coronary angiograms were analyzed off-line in a blinded fashion with the use of digital calipers to measure stenosis severity, and stenosis was defined as a dichotomous variable: if a stenotic lesion was $\geq 70 \%$, that vessel was counted as stenosed. The presence or absence of stenotic disease was also noted. Patients were ranked as having 0- to 3-vessel disease (number of coronary arteries with detectable atherosclerotic disease). For each patient, $\mathrm{K}_{3}$ EDTA arterial blood $(5 \mathrm{~mL})$ was collected just prior to coronary angiography. Blood samples were centrifuged (3,000 g) and $400 \mu \mathrm{l}$ plasma samples were stored at $-80^{\circ} \mathrm{C}$ until RNA isolation.

In a separate smaller study, blood was obtained from healthy consented volunteers $(n=5 ; 3$ female, 2 male, average age $=45)$ at 
Boston University School of Medicine as previously described ${ }^{33}$. The study was approved by Boston University IRB and written consent obtained from the subjects. All subjects were free of medications or supplements, and had no history of hypertension, diabetes, smoking, or hyperlipidemia. Blood was collected into PAXgene RNA tubes (Becton Dickinson, Franklin Lakes, NJ) for whole blood, into CPT tubes (Becton Dickinson) for peripheral blood mononuclear cells (PBMCs), into citrate tubes for platelets and plasma, and empty tubes for serum. Isolated platelets were prepared as previously described.

RNA isolation: Total RNA including miRNAs was isolated from $200 \mu \mathrm{l}$ plasma samples using miRVana Paris Kit (Ambion, Austin, TX). The RNA samples were stored at $-80^{\circ} \mathrm{C}$ until cDNA conversion.

cDNA conversion: Isolated RNA samples were converted to cDNA using miScript Reverse Transcription Kit (Qiagen, Germantown, $\mathrm{MD})$. The RNA was converted to cDNA using the following conditions: $37^{\circ} \mathrm{C}$ for $60 \mathrm{~min}, 95^{\circ} \mathrm{C}$ for $5 \mathrm{~min}$, and $4^{\circ} \mathrm{C}$ hold until further processing or storage. cDNA samples were kept at $-80^{\circ} \mathrm{C}$ until PCR analysis.

Pre-amplification: Prior to PCR, cDNA samples were pre-amplified using Taqman PreAmp Master Mix (Applied Biosystems, Foster City, CA). PreAmp Master Mix and 0.2x Primers were added to the cDNA samples and pre-amplified as follows: $95^{\circ} \mathrm{C}$ for $10 \mathrm{~min}$ once, $95^{\circ} \mathrm{C}$ for $15 \mathrm{sec}, 55^{\circ} \mathrm{C}$ for $30 \mathrm{sec}, 70^{\circ} \mathrm{C}$ for $4 \mathrm{~min}$ (final three steps repeated for 14 cycles).

qRT-PCR: Quantitative Real-Time PCR reactions (qRT-PCR) were performed using the high-throughput BioMark Real-Time PCR system (Fluidigm, South San Francisco, CA). Pre-amplified cDNA samples were diluted with 0.1mM EDTA in TE Buffer (1:5) and mixed with Power Sybr Green PCR Master Mix (Applied Biosystems), AmpliTaq Gold DNA Polymerase (Applied Biosystems) and Sample Loading Reagent (Fluidigm), then pipetted into sample inlets of Dynamic Array 96.96 chips (Fluidigm). Assay Loading Reagent (Fluidigm) and primers (Qiagen) were mixed and pipetted into assay inlets of Dynamic Array 96.96 chips. The IFC Controller HX (Fluidigm) was used to distribute primers and samples into chip reaction wells for qRT-PCR by microfluidic delivery. Gene expression experiments performed at Mersin and Gaziantep Universities in Turkey. The data were normalized using RNU1A1. Coefficient variations were less than $10 \%$ for almost all of the assays. Plasma volumes for all samples were constant $(200 \mu \mathrm{l})$ and all following steps such as cDNA, PreAmplification and qRT-PCR had the same volumes always for all samples.

\section{Statistics}

When examining miRNAs that had larger fold changes between the CAD groups (Figure 1 and Figure 2) and those more highly expressed in the circulation using similar bioinformatics methods (such as targetscan), there were many miRNA targets that are known to control the processes important in the development of atherosclerosis (list not shown).

\section{Univariate and bivariate analysis}

We initially summarized our data in different stratifications based on our outcome variables (coronary disease status). Next, we examined the bivariate relationship between the response variable and quantitative covariates using either two-sample t-test or KruskalWallis test, where appropriate. Specifically, the t-test was conducted to test for a mean difference in quantitative demographic variables and miRNA expression level between two categories of coronary disease status. The pooled variance or the Satterthwaite's method was used to estimate variance based on the equality of variance test. We employed Kruskal-Wallis test to determine whether there was any mean difference among groups in the scenario with three-category outcome variable.

\section{Multivariate analysis}

Tree-based methods have been increasingly applied to biological research such as microarray data analysis and genome-wide association studies ${ }^{34,35}$. RandomForest is a flexible nonparametric approach, which consists of many decision trees from bootstrap samples. In this study, we constructed randomForest $\mathrm{t}^{25}$ in identifying relevant variables to our outcome variable using the randomForest package in $\mathrm{R}(2.10 .1)^{36}$. Furthermore, we also conducted logistic regression and multinomial logistic regression where appropriate $^{37}$.

\section{Author contributions}

All authors contributed to this work. There were no paid authors or writing assistants used in the preparation of the manuscript or analysis of the data. All authors declare that the did not submit related or duplicate manuscripts elsewhere. Jane E. Freedman, MD: design of the study and writing the manuscript. Bahadir Ercan, $\mathrm{PhD}$ : conducting the PCR analysis. Kristine M. Morin, MPH: analyzing the data. Ching-Ti Liu, PhD: analyzing the data. Lulufer Tamer, PhD: recruiting patient and collecting the blood samples and conducting the RNA isolations. Lokman Ayaz, MSc: conducting the RNA isolations. Mehmet Kanadasi, MD, Dilek Cicek, MD, Ali Ihsan Seyhan, MD, Rabia Eker Akilli, MD, Celalettin Camci, MD, and Beyhan Cengiz, PhD: recruiting patients and collecting the blood samples. Serdar Oztuzcu, MD: conducting the PCR analysis. Kahraman Tanriverdi, PhD: design of the study, conducting the PCR analysis and writing the manuscript.

\section{Competing interests}

No competing interests were disclosed.

\section{Grant information}

This work was partially supported by HL087201 (Jane E. Freedman.).

The funders had no role in study design, data collection and analysis, decision to publish, or preparation of the manuscript. 
1. Bartel DP: MicroRNAs: genomics, biogenesis, mechanism, and function. Cell. 2004; 116: 281-297.

PubMed Abstract | Publisher Full Text

2. Ambros $\mathrm{V}$, Chen $\mathrm{X}$ : The regulation of genes and genomes by small RNAs. Development. 2007; 134: 1635-1641. PubMed Abstract | Publisher Full Text

3. Winter J, Jung S, Keller S, et al.: Many roads to maturity: microRNA biogenesis pathways and their regulation. Nat Cell Biol. 2009; 11: 228-234. PubMed Abstract | Publisher Full Text

4. Suarez Y, Sessa WC: MicroRNAs as novel regulators of angiogenesis. Circ Res. 2009; 104: 442-454.

PubMed Abstract | Publisher Full Text | Free Full Text

5. Filipowicz W, Bhattacharyya SN, Sonenberg N: Mechanisms of posttranscriptional regulation by microRNAs: are the answers in sight? Nat Rev Genet. 2008; 9: 102-114.

PubMed Abstract | Publisher Full Text

6. Griffiths-Jones S, Saini HK, van Dongen S, et al.: miRBase: tools for microRNA genomics. Nucleic Acids Res. 2008; 36: D154-158 PubMed Abstract | Publisher Full Text | Free Full Text

7. Huang J, Liang Z, Yang B, et al.: Derepression of microRNA-mediated protein translation inhibition by apolipoprotein B mRNA-editing enzyme catalytic polypeptide-like 3G (APOBEC3G) and its family members. J Biol Chem. 2007; 282: 33632-33640.

PubMed Abstract | Publisher Full Text

8. Rana TM: Illuminating the silence: understanding the structure and function of small RNAs. Nat Rev Mol Cell Biol. 2007; 8: 23-36. PubMed Abstract | Publisher Full Text

9. Landry P, Plante I, Ouellet DL, et al:: Existence of a microRNA pathway in anucleate platelets. Nat Struct Mol Biol. 2009; 16: 961-966. PubMed Abstract | Publisher Full Text | Free Full Text

10. Ai J, Zhang R, Li Y, et al.: Circulating microRNA-1 as a potential novel biomarker for acute myocardial infarction. Biochem Biophys Res Commun. 2010; 391: 73-77.

PubMed Abstract | Publisher Full Text

11. Hoekstra M, van der Lans CA, Halvorsen B, et al:: The peripheral blood mononuclear cell microRNA signature of coronary artery disease. Biochem Biophys Res Commun. 2010; 394: 792-797. PubMed Abstract | Publisher Full Text

12. Ramkissoon $\mathrm{SH}$, Mainwaring LA, Ogasawara $Y$, et al: Hematopoietic-specific microRNA expression in human cells. Leuk Res. 2006; 30: 643-647. PubMed Abstract | Publisher Full Text

13. Merkerova M, Belickova $\mathrm{M}$, Bruchova $\mathrm{H}$ : Differential expression of microRNAs in hematopoietic cell lineages. Eur J Haematol. 2008; 81: 304-310. PubMed Abstract | Publisher Full Text

14. Mitchell PS, Parkin RK, Kroh EM, et al.: Circulating microRNAs as stable bloodbased markers for cancer detection. Proc Natl Acad Sci USA. 2008; 105 10513-10518.

PubMed Abstract | Publisher Full Text | Free Full Text

15. Care A, Catalucci D, Felicetti F, et al:: MicroRNA-133 controls cardiac hypertrophy. Nat Med. 2007; 13: 613-618. PubMed Abstract | Publisher Full Text

16. Latronico MV, Catalucci D, Condorelli G: MicroRNA and cardiac pathologies. Physiol Genomics. 2008; 34: 239-242. PubMed Abstract | Publisher Full Text

17. Bostjancic $E$, Zidar N, Glavac D: MicroRNA microarray expression profiling in human myocardial infarction. Dis Markers. 2009; 27: 255-268. PubMed Abstract | Publisher Full Text

18. Dong S, Cheng $\mathrm{Y}$, Yang J, et al.: MicroRNA expression signature and the role of microRNA-21 in the early phase of acute myocardial infarction. $J$ Biol Chem 2009; 284: 29514-29525.

PubMed Abstract | Publisher Full Text | Free Full Text
19. Wang GK, Zhu JQ, Zhang JT, et al: Circulating microRNA: a novel potential biomarker for early diagnosis of acute myocardial infarction in humans. Eur Heart J. 2010; 31: 659-666.

PubMed Abstract | Publisher Full Text

20. Kondkar AA, Bray MS, Leal SM, et al: VAMP8/endobrevin is overexpressed in hyperreactive human platelets: suggested role for platelet microRNA. $J$ Thromb Haemost. 2010; 8: 369-378.

PubMed Abstract | Publisher Full Text | Free Full Text

21. Sato F, Tsuchiya S, Terasawa $\mathrm{K}$, et al.: Intra-platform repeatability and inter-platform comparability of microRNA microarray technology. PLoS One. 2009; 4: e5540.

PubMed Abstract | Publisher Full Text | Free Full Text

22. Spurgeon SL, Jones RC, Ramakrishnan R: High throughput gene expression measurement with real time PCR in a microfluidic dynamic array. PLoS One. 2008; 3(2): e1662.

PubMed Abstract | Publisher Full Text | Free Full Text

23. Lee $\mathrm{Y}, \mathrm{Kim} \mathrm{M}, \mathrm{Han} \mathrm{J}$, et al:: MicroRNA genes are transcribed by RNA polymerase II. Embo J. 2004; 23: 4051-4060. PubMed Abstract | Publisher Full Text | Free Full Text

24. Hutvagner G, Zamore PD: A microRNA in a multiple-turnover RNAi enzyme complex. Science. 2002; 297: 2056-2060.

PubMed Abstract | Publisher Full Text

25. Meister G, Landthaler M, Patkaniowska A, et al.: Human Argonaute2 mediates RNA cleavage targeted by miRNAs and siRNAs. Mol Cell. 2004; 15: 185-197. PubMed Abstract | Publisher Full Text

26. Ambros V, Lee RC, Lavanway A, et al:: MicroRNAs and other tiny endogenous RNAs in C. elegans. Curr Biol. 2003; 13: 807-818.

PubMed Abstract | Publisher Full Text

27. Pillai RS, Bhattacharyya SN, Filipowicz W: Repression of protein synthesis by miRNAs: how many mechanisms? Trends Cell Biol. 2007; 17: 118-126. PubMed Abstract | Publisher Full Text

28. Italiano JE Jr, Bergmeier W, Tiwari S, et al.: Mechanisms and implications of platelet discoid shape. Blood. 2003; 101: 4789-4796. PubMed Abstract | Publisher Full Text

29. Kieffer N, Guichard J, Farcet JP, et al.: Biosynthesis of major platelet proteins in human blood platelets. Eur J Biochem. 1987; 164: 189-195. PubMed Abstract | Publisher Full Text

30. Denis MM, Tolley ND, Bunting M, et al.: Escaping the nuclear confines: signaldependent pre-mRNA splicing in anucleate platelets. Cell. 2005; 122: 379-391. PubMed Abstract | Publisher Full Text

31. Vickers KC, Palmisano BT, Shoucri BM, et al:: MicroRNAs are transported in plasma and delivered to recipient cells by high-density lipoproteins. Nat Cell Biol. 2011; 13: 423-433.

PubMed Abstract | Publisher Full Text | Free Full Text

32. Wang R, Li N, Zhang $Y$, et al.: Circulating MicroRNAs are Promising Novel Biomarkers of Acute Myocardial Infarction. Intern Med. 2011: 50: 1789-1795. PubMed Abstract | Publisher Full Text

33. Freedman JE, Ting B, Hankin B, et al:: Impaired platelet production of nitric oxide predicts presence of acute coronary syndromes. Circulation. 1998; 98 : 1481-1486.

PubMed Abstract | Publisher Full Text

34. Zhang $\mathrm{H}, \mathrm{Yu} \mathrm{CY}$, Singer $\mathrm{B}$ : Cell and tumor classification using gene expression data: construction of forests. Proc Natl Acad Sci USA. 2003; 100: 4168-4172. PubMed Abstract | Publisher Full Text | Free Full Text

35. Chen X, Liu CT, Zhang M, et al:: A forest-based approach to identifying gene and gene gene interactions. Proc Natl Acad Sci USA. 2007; 104: 19199-19203. PubMed Abstract | Publisher Full Text | Free Full Text

36. Breiman L: Random Forests. Machine Learning. 2001; 45: 5-32. Publisher Full Text

37. Liaw A, Wiener M: Classification and Regression by random Forest. $R$ News. 2002; 2/3: 18-22.

Reference Source 


\title{
Open Peer Review
}

\section{Current Peer Review Status:}

\section{Version 1}

Reviewer Report 11 January 2013

https://doi.org/10.5256/f1000research.221.r701

(C) 2013 Clancy J. This is an open access peer review report distributed under the terms of the Creative Commons Attribution License, which permits unrestricted use, distribution, and reproduction in any medium, provided the original work is properly cited.

\begin{abstract}
Jennifer Clancy
Genome Biology Department, John Curtin School of Medical Research, ANU College of Medicine, Biology \& Environment, The Australian National University, Canberra, Australia

I would like to note that the manuscript could be improved by use of error bars in Figures 1 and 2 to display some measure of variance and that future studies of this type could utilise spike-ins prior to RNA extraction to normalise for variability in RNA extractions between samples.
\end{abstract}

Competing Interests: No competing interests were disclosed.

I confirm that I have read this submission and believe that I have an appropriate level of expertise to confirm that it is of an acceptable scientific standard.

Reviewer Report 09 January 2013

https://doi.org/10.5256/f1000research.221.r652

C 2013 Elton T. This is an open access peer review report distributed under the terms of the Creative Commons Attribution License, which permits unrestricted use, distribution, and reproduction in any medium, provided the original work is properly cited.

\section{Terry Elton}

Division of Pharmacology, OSU College of Pharmacy, Columbus, Ohio, USA

Competing Interests: No competing interests were disclosed.

I confirm that I have read this submission and believe that I have an appropriate level of expertise to confirm that it is of an acceptable scientific standard. 
Reviewer Report 26 November 2012

https://doi.org/10.5256/f1000research.221.r381

(c) 2012 Sarnow P. This is an open access peer review report distributed under the terms of the Creative Commons Attribution License, which permits unrestricted use, distribution, and reproduction in any medium, provided the original work is properly cited.

\section{Peter Sarnow}

Department of Microbiology and Immunology, Stanford University, Stanford, CA, USA

Competing Interests: No competing interests were disclosed.

I confirm that I have read this submission and believe that I have an appropriate level of expertise to confirm that it is of an acceptable scientific standard.

\section{Comments on this article}

\section{Version 1}

Reader Comment ( ) 12 Jun 2013

James Timmons, Department of Medical \& Molecular Genetics, King's College London, UK

Examination of the CT values for the miRs indicates that many are not being run within the normal linear range. That hampers any interpretation of correlations down-stream. Neither Taqman nor microarray data for miR expression can be directly converted to statement of abundance either. This represents a failure in the technical review of this work.

Competing Interests: none 
The benefits of publishing with F1000Research:

- Your article is published within days, with no editorial bias

- You can publish traditional articles, null/negative results, case reports, data notes and more

- The peer review process is transparent and collaborative

- Your article is indexed in PubMed after passing peer review

- Dedicated customer support at every stage

For pre-submission enquiries, contact research@f1000.com 